\title{
Jekyll or Hyde: does Matrigel provide a more or less physiological environment in mammary repopulating assays?
}

\author{
François Vaillant ${ }^{1,2}$, Geoffrey J Lindeman ${ }^{1,3,4}$ and Jane E Visvader ${ }^{1,2 *}$
}

\begin{abstract}
In vivo transplantation is the current 'gold-standard' assay for evaluating mammary stem cell (MaSC) function. Matrigel, a reconstituted extracellular matrix derived from a mouse sarcoma line, is increasingly being utilized for mammary repopulating assays, although original studies were carried out in its absence. This matrix has also been shown to enhance tumor-initiating capacity. Whilst Matrigel increases the rate of engraftment by MaSCs, it also appears to promote progenitor activity that is distinct from bona fide stem cell activity. This caveat should be considered when interpreting mammary reconstitution assays that incorporate Matrigel, particularly when transplanting high cell numbers.
\end{abstract}

In vivo transplantation into the mammary fat pad represents the cornerstone assay for evaluating mammary stem cell (MaSC) activity. Pioneering work has shown that mammary epithelial outgrowths can be generated in de-epithelialized (or cleared) fat pads transplanted with explants or admixtures of mammary cells [1]. More recently, MaSCs have been prospectively isolated and demonstrated to exhibit multilineage differentiation and self-renewal properties through the transplantation of limiting numbers of empirically derived cell subpopulations. A MaSC-enriched basal population was identified on the basis of high expression of integrin $\beta_{1}$ (CD29) or integrin $\alpha_{6}(\mathrm{CD} 49 \mathrm{f})$ and moderate levels of CD24 [2,3], with an estimated stem cell frequency of 1 in 60. Using CD24 as a single marker, the CD24 $4^{\text {mod }}$ subset was shown to comprise almost all repopulating activity $[4,5]$.

\footnotetext{
*Correspondence: visvader@wehi.edu.au
}

'Stem Cells and Cancer Division, The Walter and Eliza Hall Institute of Medical

Research, 1G Royal Parade, Parkville,"VIC 3052, Australia

Full list of author information is available at the end of the article
A number of recent studies have incorporated the reconstituted extracellular matrix Matrigel (BD Biosciences) in their mammary transplantation assays, with a view to creating an improved microenvironment for the implantation of stem cells. These studies have included the transplantation of unsorted mammary cells, in which as few as 100 cells could reconstitute an entire mammary gland [6], and the transplantation of sorted epithelial subpopulations embedded in Matrigel [7-10]. Interestingly, Matrigel was recently shown to enhance melanoma cell tumor-initiating capacity several-fold [11]. Given the increasing use of Matrigel in transplantation assays, we have directly assessed the effect of this matrix on the repopulating capacity of two distinct subpopulations isolated from normal mouse mammary glands: the MaSC-enriched subset and the luminal cell subset, the latter of which comprises committed luminal progenitor and mature luminal cells. We report here that the luminal subpopulation can yield limited ductal outgrowths, but only in the presence of Matrigel. These data raise the possibility that rare bipotent cells in this subset are activated by matrix components or that committed luminal progenitor cells can undergo dedifferentiation. In either case, these cells do not represent true MaSCs.

MaSCs have previously been shown to lie within the CD29 $9^{\text {hi }}$ (or CD49f ${ }^{\text {hi }}$ ) CD24 $4^{+}$population, while extensive transplantation assays of luminal cell fractions including the $\mathrm{CD} 61^{+}$luminal progenitor subset have demonstrated that this luminal population lacks repopulating potential $[2,3,12]$. In human breast tissue, stem cell activity was similarly demonstrated to occur in the basal population $[13,14]$. To address the influence of Matrigel on in vivo mammary repopulating capacity, we transplanted doublesorted cells from the MaSC-enriched subset $\left(\mathrm{CD} 29^{\mathrm{hi}} \mathrm{CD} 24^{+}\right)$ and the luminal subset $\left(\mathrm{CD} 29^{\text {lo }} \mathrm{CD} 24^{+}\right)$in either $0 \%, 25 \%$ or $50 \%$ Matrigel. Donor cells were derived from Rosa26 mice to allow definitive identification of outgrowths from implanted cells by virtue of $\beta$-galactosidase activity. Cells within the $\mathrm{CD} 29^{\text {hi }} \mathrm{CD} 24^{+}$subset were transplanted at limiting dilution, in which 1 in 75 cells is estimated to be a MaSC [2], while an excess of luminal cells (1,000 cells) 
a

\begin{tabular}{lcccccc}
\hline Cell population & \multicolumn{4}{c}{$\%$ Matrigel in transplant buffer } \\
\cline { 2 - 6 } & \multicolumn{2}{c}{0} & \multicolumn{2}{c}{25} & \multicolumn{2}{c}{50} \\
\cline { 2 - 6 } CD29 $^{\text {hi CD24 }}{ }^{+}$ & $18 / 40$ & $(45.0 \%)$ & $17 / 28$ & $(60.7 \%)$ & $35 / 40$ & $(87.5 \%)$ \\
CD29. $^{\circ} \mathrm{CD} 24^{+}$ & $0 / 40$ & $(0 \%)$ & $3 / 28$ & $(10.7 \%)$ & $9 / 40$ & $(22.5 \%)$
\end{tabular}

b

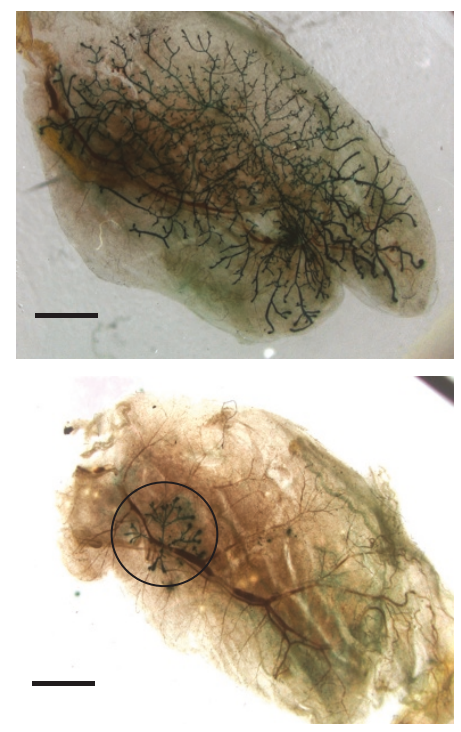

C
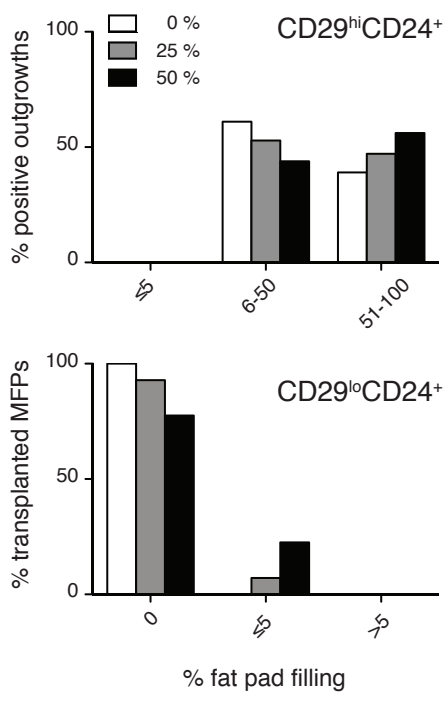

Figure 1. Effect of Matrigel on the transplantation of mammary epithelial cell subpopulations. (a) Table showing the number of outgrowths per number of mammary fad pads injected with either 75 CD29hiCD24+ (mammary stem cell (MaSC)-enriched) cells or 1,000 CD29.0 ${ }^{\circ} 24^{+}$ (luminal) cells, in either $0 \%, 25 \%$ or $50 \%$ Matrigel. Single cell suspensions were prepared from the mammary glands of 8-week-old to 10-week-old FVB/N-Rosa26 female mice, labeled with fluorochrome-conjugated antibodies and double-sorted as described [2]. The MaSC-enriched and luminal cell populations were identified following depletion of endothelial and hematopoietic cells using anti-CD45, anti-CD31 and anti-TER1 19 antibodies. Cells were injected (10 $\mu \mathrm{l}$ volume) into the cleared inguinal mammary fat pads of 3-week-old FVB/N female recipients and were collected 8 weeks post transplantation for $X$-gal staining. $\beta$-Gal ${ }^{+}$branched ductal structures were scored as positive. Data are shown for four independent experiments. (b) Images of X-gal-stained outgrowths: outgrowth derived from transplantation of 75 CD29 $9^{\text {hi }} \mathrm{CD} 24^{+}$cells in $50 \%$ Matrigel (top), and largest outgrowth obtained from transplantation of 1,000 CD29 ${ }^{\circ} \mathrm{CD} 24^{+}$cells in 50\% Matrigel (bottom). Bar $=1 \mathrm{~mm}$. (c) Bar chart representation of mammary outgrowths as a function of fat-pad filling following transplantation of each subpopulation. The axes shown differ for the two populations, since very few structures were generated by the CD29 ${ }^{\circ} \mathrm{CD} 24^{+}$population and these did not exceed 5\%. Data are shown for four independent experiments. MFP, mammary fat pad.

were injected. Matrigel at both concentrations was found to substantially enhance the mammary repopulating frequency of the MaSC-enriched subpopulation, with the percentage of outgrowths from transplanted cells almost doubling in the presence of 50\% Matrigel compared with no Matrigel (Figure 1). In general, more extensive filling of the fat pad was apparent in the presence of this matrix. These data are compatible with the increased engraftment observed upon inclusion of 50\% Matrigel [9]. Constituents within Matrigel may enhance the viability and/or activity of stem cells, resulting in increased repopulating capacity.
Unexpectedly, transplantation of the luminal subpopulation in Matrigel gave rise to small branched structures (Figure 1a,b): $10.7 \%$ and $22.5 \%$ were observed in the presence of $25 \%$ and $50 \%$ Matrigel, respectively. No outgrowths, however, were generated from this subpopulation in the absence of Matrigel, consistent with previous studies $[2,3]$. Notably, only diminutive outgrowths arose from luminal subset cells inoculated in 50\% Matrigel, although each structure exhibited ductal branching from a central point and was therefore scored (Figure 1b,c). In the case of $25 \%$ Matrigel, the structures filled approximately $1 \%$ of the fat pad. 
Secondary transplantation experiments were carried out from luminal cell-derived $(n=3)$ or MaSC-derived $(n=3)$ outgrowths to determine whether the luminal cell-derived outgrowths contained cells with self-renewal capacity. No outgrowths were present in 20 recipient glands, whereas prominent ductal outgrowths were evident in recipient glands from all three MaSC-derived outgrowths (15/20). Thus the Matrigel-associated luminal cell-derived $\left(\mathrm{CD} 29^{\mathrm{lo}} \mathrm{CD} 24^{+}\right)$outgrowths did not exhibit self-renewal properties, a hallmark feature of stem cells.

Contamination of this luminal subpopulation (doublesorted and purity confirmed by reanalysis) with MaSCs seems unlikely as no outgrowths were evident in the absence of Matrigel, and no extensive outgrowths were ever observed. Rather, Matrigel may be providing a microenvironment that activates rare bipotent progenitor cells capable of regeneration, albeit limited. Alternatively, luminal progenitor cells within this subpopulation may occasionally adopt a more primitive state. These data differ from those recently reported in which Matrigel was found to be necessary for the generation of outgrowths from both the $\mathrm{CD} 49 \mathrm{f}^{\mathrm{hi}} \mathrm{CD} 24^{\mathrm{med}}$ and $\mathrm{CD} 49 \mathrm{f}^{\mathrm{lo}} \mathrm{CD} 24^{\mathrm{hi}}$ subpopulations [10]. Contrary to the findings described here, a similar degree of engraftment was noted for each population, perhaps reflecting the large number of cells transplanted (50,000 cells) [10].

It is conceivable that the activation of signaling pathways by Matrigel components can stimulate certain cells to acquire a more primitive state. Matrigel is a solubilized basement membrane extracted from Engelbreth-HolmSwarm mouse sarcoma and is rich in laminin, collagen IV, proteoglycans as well as a number of different growth factors [15]. The nature of the substance or growth factors in Matrigel that may confer a more permissive environment for progenitor activity is yet to be determined. Growth factor-reduced Matrigel could be considered an alternative to complete Matrigel to perhaps distinguish effects of the substratum components from those of growth factors on mammary reconstitution.

Matrigel has been widely used to study tumor cell invasion, and an altered extracellular matrix has been shown to promote tumorigenesis [16]. In xenotransplantation assays to identify cancer stem cells in primary tumors, it is pertinent that only the cancer stem cell fraction and not the negative fraction had tumorinitiating capacity in mice when inoculated in Matrigel [17]. This reconstituted basement membrane, however, has been found to facilitate tumorigenesis of human breast cancers, squamous cell carcinomas and teratomas in mice [18-20], suggesting it has the potential to provide tumor cells with additional survival and/or proliferative signals. The influence of Matrigel on established tumors, however, is a distinct question from its impact on normal cells.
In summary, our data suggest that, in addition to increasing the rate of engraftment by MaSCs, Matrigel appears to promote progenitor activity in the luminal subset that is not seen in its absence. It is important to note that these cells with limited regenerative potential are distinct from bona fide MaSCs that lie within the basal population and should not be scored as such. A degree of caution should thus be applied to interpreting data from mammary cell transplantation experiments that incorporate Matrigel, particularly when transplanting high cell numbers. Additional studies (such as comparison of complete Matrigel and growth factor-reduced Matrigel) will be required to resolve the question of whether it is more or less physiological to include this matrix in transplantation assays for MaSC function.

\section{Abbreviations}

MaSC, mammary stem cell.

\section{Competing interests}

The authors declare that they have no competing interests.

\section{Acknowledgments}

GJL and JEV are funded by the Victorian Government, through Victorian Cancer Agency funding of the Victorian Breast Cancer Research and by the National Health and Medical Research Council Australia.

\section{Author details}

'Stem Cells and Cancer Division,The Walter and Eliza Hall Institute of Medical Research, 1 G Royal Parade, Parkville, VIC 3052, Australia. ${ }^{2}$ Department of Medical Biology, The University of Melbourne, Parkville, VIC 3010, Australia. 3Department of Medical Oncology, The Royal Melbourne Hospital, Grattan Street, Parkville, VIC 3050, Australia. ${ }^{4}$ Department of Medicine, The University of Melbourne, Parkville, VIC 3010, Australia.

Published: 25 May 2011

\section{References}

1. Daniel CW, De Ome KB, Young JT, Blair PB, Faulkin $\sqcup$, Jr: The in vivo life span of normal and preneoplastic mouse mammary glands: a serial transplantation study. Proc Natl Acad Sci U S A 1968, 61:53-60.

2. Shackleton M, Vaillant F, Simpson KJ, Stingl J, Smyth GK, Asselin-Labat ML, Wu L, Lindeman GJ, Visvader JE: Generation of a functional mammary gland from a single stem cell. Nature 2006, 439:84-88.

3. Stingl J, Eirew P, Ricketson I, Shackleton M, Vaillant F, Choi D, Li HI, Eaves CJ: Purification and unique properties of mammary epithelial stem cells. Nature 2006, 439:993-997.

4. Sleeman KE, Kendrick H, Ashworth A, Isacke CM, Smalley MJ: CD24 staining of mouse mammary gland cells defines luminal epithelial, myoepithelial/ basal and non-epithelial cells. Breast Cancer Res 2006, 8:R7

5. Sleeman KE, Kendrick H, Robertson D, Isacke CM, Ashworth A, Smalley MJ: Dissociation of estrogen receptor expression and in vivo stem cell activity in the mammary gland. $J$ Cell Bio/ 2007, 176:19-26.

6. Moraes RC, Zhang X, Harrington N, Fung JY, Wu MF, Hilsenbeck SG, Allred DC, Lewis MT: Constitutive activation of smoothened (SMO) in mammary glands of transgenic mice leads to increased proliferation, altered differentiation and ductal dysplasia. Development 2007, 134:1231-1242.

7. Badders NM, Goel S, Clark RJ, Klos KS, Kim S, Bafico A, Lindvall C, Williams BO, Alexander CM: The Wnt receptor, Lrp5, is expressed by mouse mammary stem cells and is required to maintain the basal lineage. PLoS One 2009, 4:e6594.

8. Gu B, Sun P, Yuan Y, Moraes RC, Li A, Teng A, Agrawal A, Rheaume C Bilanchone V, Veltmaat JM, Takemaru K, Millar S, Lee EY, Lewis MT, Li B, Dai X: Pygo2 expands mammary progenitor cells by facilitating histone $\mathrm{H} 3 \mathrm{~K} 4$ methylation. J Cell Biol 2009, 185:811-826.

9. Zeng YA, Nusse R: Wnt proteins are self-renewal factors for mammary stem cells and promote their long-term expansion in culture. Cell Stem Cell 2010, 
6:568-577.

10. Jeselsohn R, Brown NE, Arendt L, Klebba I, Hu MG, Kuperwasser C, Hinds PW: Cyclin $D_{1}$ kinase activity is required for the self-renewal of mammary stem and progenitor cells that are targets of MMTV-ErbB2 tumorigenesis. Cancer Cell 2010, 17:65-76.

11. Quintana E, Shackleton M, Sabel MS, Fullen DR, Johnson TM, Morrison SJ: Efficient tumour formation by single human melanoma cells. Nature 2008 456:593-598.

12. Bouras T, Pal B, Vaillant F, Harburg G, Asselin-Labat ML, Oakes SR, Lindeman GJ, Visvader JE: Notch signaling regulates mammary stem cell function and luminal cell-fate commitment. Cell Stem Cell 2008, 3:429-441.

13. Eirew P, Stingl J, Raouf A, Turashvili G, Aparicio S, Emerman JT, Eaves CJ: A method for quantifying normal human mammary epithelial stem cells with in vivo regenerative ability. Nat Med 2008, 14:1384-1389.

14. Lim E, Vaillant F, Wu D, Forrest NC, Pal B, Hart AH, Asselin-Labat ML, Gyorki DE, Ward T, Partanen A, Feleppa F, Huschtscha LI, Thorne HJ, Fox SB, Yan M, French JD, Brown MA, Smyth GK, Visvader JE, Lindeman GJ: Aberrant luminal progenitors as the candidate target population for basal tumor development in BRCA1 mutation carriers. Nat Med 2009, 15:907-913.

15. Kleinman HK, McGarvey ML, Liotta LA, Robey PG, Tryggvason K, Martin GR Isolation and characterization of type IV procollagen, laminin, and heparan sulfate proteoglycan from the EHS sarcoma. Biochemistry 1982, 21:6188-6193.
16. Bissell MJ, Labarge MA: Context, tissue plasticity, and cancer: are tumor stem cells also regulated by the microenvironment? Cancer Cell 2005, 7:17-23.

17. Visvader JE, Lindeman GJ: Cancer stem cells in solid tumours: accumulating evidence and unresolved questions. Nat Rev 2008 , 8:755-768.

18. Henson B, Li F, Coatney DD, Carey TE, Mitra RS, Kirkwood KL, D'Silva NJ: An orthotopic floor-of-mouth model for locoregional growth and spread of human squamous cell carcinoma. J Oral Pathol Med 2007, 36:363-370.

19. Mehta RR, Graves JM, Hart GD, Shilkaitis A, Das Gupta TK: Growth and metastasis of human breast carcinomas with Matrigel in athymic mice. Breast Cancer Res Treat 1993, 25:65-71.

20. Prokhorova TA, Harkness LM, Frandsen U, Ditzel N, Burns JS, Schroeder HD, Kassem M: Teratoma formation by human embryonic stem cells is sitedependent and enhanced by the presence of Matrigel. Stem Cells Dev 2009, 18:47-54.

doi:10.1186/bcr2851

Cite this article as: Vaillant F, et al: Jekyll or Hyde: does Matrigel provide a more or less physiological environment in mammary repopulating assays? Breast Cancer Research 2011, 13:108. 